\title{
EXPLORATION OF PROMOTION AND FACILITIES FACTORS THAT AFFECT ON TOURISTS' DECISIONS TO VISIT MANADO CITY, INDONESIA
}

\author{
Loindong Sjendry S.R. ${ }^{\star}$, Walangitan Mac Donald, Raintung Michael Ch. \\ University of Sam Ratulangi, Manado, Indonesia \\ *E-mail: loindong18s@gmail.com
}

\begin{abstract}
This study aims to determine the effect of Promotion and Facilities on tourists' decisions to visit Manado city. This was descriptive qualitative research employing a case study method. The researchers conducted interviews with 10 tourists visiting Manado city. These research results conclude that tourism promotion in Manado city can reach most tourists who come there, meaning that there are still tourists coming in Manado city do not know the promotion of tourism there. The results of this study also conclude that tourism facilities in Manado city have been able to meet the needs of tourists. The results of the study are expected to be a valuable input for the government in terms of policy making, for investors in making investment decisions appropriately, in addition, the results of this study can be an important reference for similar research for applied interests and development interests for the welfare of society.
\end{abstract}

\section{KEY WORDS}

Tourism, Manado, promotion, facility, public service.

Any business in modern era like today is faced with an atmosphere of competitive competition, also businesses engaged in the tourism sector also feel too.If more observed, the tourism sector tends to be more stable and even increases from year to year.Since 2013, tourism has become number four of foreign exchange contributor in Indonesia.

Tourism Minister Arief Yahya said that tourist visits from January to August of 2017 grew by 25.68 percent.This number is recorded higher than that of Singapore and Thailand, each of which only recorded a growth of 3.83 percent and 5.05 percent.

Based on these numbers, Indonesia's foreign exchange has the potential to increase by 25.68 percent from US\$13.57 billion last year to US\$17.05 billion until the end of 2017.That number, said Arief, has the potential to defeat the contribution of Crude Palm Oil (CPO) which has been predicted as the country's main foreign exchange contributor. North Sulawesi Province continues to improve in the Tourism sector.The number of foreign tourists who come to North Sulawesi through the entrance of Sam Ratulangi Airport in October 2017 increased by $21.90 \%$ compared to September 2017.Foreign tourists are still dominated by Chinese tourists as much as $77.36 \%$, then followed by German tourists by $3.66 \%$, followed by tourists from Singapore amounting to 2.63\%. Data on tourist visits until November 2017 has reached 85,000 tourists.

Tourism in Bumi Nyiur Melambai, shows significant growth.No wonder if to boost tourist visits, Manado city targets as many as 200 thousand people until 2019.A number of events were held by the government of Manado city to promote tourism in Manado city. Among them is the holding of the 2017 Indonesian Film Festival held in the city of Manado.Then the government of Manado city also held the 2017 Manado Fiesta, which aims to realize one of the expectations of the city government, which is to make Manado a world tourism city.

Bunaken Marine National Park is again included in the top 10 of the leading destinations for Indonesian Tourism Branding in 2017. This news is very giving fresh wind to the world of tourism in Manado city. In addition to the cultural tourism of old Chinatown, Manado also gives various options for tourists to visit.

Mingkid (2015) through his study of the utilization of tourism promotion communication media by the Manado city government found that the use of communication media for the tourism promotion activities has not made tourism promotion going well. It is due to the lack 
of funds to finance operations, network systems often have problems, the absence of employees in the organizational structure regularly having expertise in the field of information technology and graphic design, as well as office facilities and infrastructure including office buildings that are not yet adequate.Therefore the Government of Manado City needs to utilize it.

A number of tourist facilities are gradually addressed by the city government of Manado with the community.Hotels, restaurants and transportation had been prepared during the World Ocean Conference (WOC) in Manado in 2009. Then followed by other activities such as Sail Bunaken. This international event initiated by academics and scientists adds to the history of Sulwada for international activities held in Manado city including the 2012 Asia Solidarity Economic Forum.

International activities like World Ocean Conference (WOC), CTI Summit, Sail Bunaken, ASEAN Regional Forum Disaster Relief Exercise (ARF DiREx) and ASEAN Tourism Forum, and so many events carried out actually support Manado as one of the objectives of MICE (Meeting, Invention, Convention, Exhibition).

But it turned out that there were still complaints from tourists about the lack of public facilities such as toilets and its facilities at tourist sites.Likewise, the news from Tempo.co online news media stating that supporting facilities in Bunaken, from tourism support infrastructure, lodging facilities to guides are considered not good, making tourists uncomfortable.

From the description of the background, the problems in this study are:Do Promotion and Facilities influence the decisions of tourists to visit Manado?

This study has a special purpose in the first year, namely to determine the effect of promotion and facility factors on the decisions of tourists to visit Manado city.In the second year, this study aims to determine the effect of other than promotion and facility factors on the decisions of tourists to visit Manado city because there are other factors that influence the decisions of tourists to visit Manado city.

The results of this study are expected to be valuable inputs for the government in terms of policy determination, for investors in making investment decisions appropriately, besides that the results of this study can be an important reference for similar research for applied interests and the interests of science development.

\section{LITERATURE REVIEW}

Marketing strategy, according to Kotler (2004), is the mindset used to achieve its marketing goals. The marketing strategy contains strategies for target markets, positioning, marketing mix and the amount of marketing expenditure.Tjiptono (2001: 6), Marketing Strategy is a fundamental tool that is planned to reach the company by developing a competitive advantage through entered markets and marketing programs used to serve the target market.Marketing aims at:

- Potential consumers know in detail the products we produce and companies can provide all their requests for the products produced;

- The company can explain in detail all activities related to marketing.Various activities, ranging from explanations about products, product design, product promotion, product advertising, communication to consumers, until the delivery of products are carried out to reach consumers quickly;

- Getting to know and understand consumers in such a way that the product matches it and can sell itself.

Marketing Mix is a set of marketing tools used by companies to pursue their corporate objectives. So, it can be concluded that the marketing mix is a device consisting of products, prices, promotions, and distributions, which will determine the level of marketing success and all of them are intended to get the desired response from the target market.(Kotler and keller, 2007)

Tjiptono (2008) proposed that product is everything that a producer can offer to pay attention to, look for, buy, use or consume the market as fulfilling the needs or desires of the 
relevant market.The products offered include physical goods such as motorbikes, computers, television, while service products include restaurants, lodging, and transportation.Products are both tangible or intangible benefits which can satisfy costumers. Conceptually, the product is a subjective understanding of the producer for something that can be offered as an effort to achieve organizational goals through the fulfilling of consumers' needs and desires in accordance with the competence and capacity of the organization and the purchasing power of the market.

Assauri (2011) defines price as the only element of the marketing mix that generates sales revenue, while other elements are only cost elements.Prices can be expressed in various terms such as fees, rates, rent, interest, premiums, commissions, wages, salaries, honorariums, contribuion and so on.From the marketing point of view, prices are monetary units or other measures (including interest and other services) that are exchanged in order to obtain ownership rights or use of an item or service (Tjiptono, 2008).

Tjiptono (2008) broadly defines that distribution can be interpreted as a marketing activity which seeks to facilitate and simplify the delivery of goods and services from producers to consumers so that the use is in accordance with what is needed (type, amount, price, place and when needed).In other words, the distribution process is a marketing activity that is able to:(1) Create product value added through marketing functions that can realize the usefulness of form, place, time and ownership:(2) Streamline the flow of marketing channels physically and non-physically. What is meant by marketing flow is the flow of activities that occur between marketing institutions involved in the marketing process.Marketing flows include fission items, ownership flows, information flows, promotion flows, negotiation flows, payment flows, funding flows, risk bearing flows and order flows.

Babin (2011) defines promotion as a function of communication from responsible companies and persuades/invites buyers.Promotion is one of the success determinants of a marketing program.Promotion is a special way of personal advertising, sales promotion and public relations that the company uses for its advertising and marketing purposes. The nature of promotion is a form of marketing communication meaning a marketing activity that seeks to disseminate information, influence/persuade and remind the target market of the company and its products to be willing to accept, buy and be loyal to the products offered by the related company, Tjiptono (2008).

Shimp (2003) explains that the existence of marketing communications in this decade has become increasingly important and been claimed that marketing is communication and communication is marketing.According to Fill (2009), there are five elements of the marketing communication mix.Those five elements include advertising, direct marketing, personal selling, public relations, and sales promotion.

Promotional factors are very important to boost the number of tourists visiting certain tourism objects, without promotion, it will be difficult to inform the public or tourists candidate to visit or travel to interesting places.

Tjiptono (2008) defines some of the purposes of promotion,among other, as follows:

- Informing: 1) Informing the market about the existence of a product, 2) Introducing new ways of using a product, 3) Delivering price changes to the market, 4) Explaining how a product works, 5) Informing the services provided by the company;

- Persuading:1) Forming brand choices, 2) Switching choices to certain brands, 3) Changing customer perceptions of product attributes, 4) Encouraging buyers to buy at that moment;

- Reminiding1) Reminding the buyer that the product in question is needed in the near future, 2) Reminding the buyer of places that sell company products, 3) Making buyers keep in mind even though they will not be full of advertisements.

Swastha (2009) proposes that the functions of promotional activities include:

- Looking for and getting the attention of the buyer;

- Creating and generating interest in buyers candidate;

- Developing a sense of desire from the buyers' candidate to have the goods offered.

Fandy Tjiptono (2001) states that facilities are physical resources that must exist before a service can be offered to consumers. Facilities can also be anything that makes it easy for 
consumers to get satisfaction.Matters related to the tourism products facility development has several components, i.e.:

- Tourism Attraction. Something that is interesting and causes tourists to visit a place/region/country is called attraction or tourist attraction;

- Available Facilities. One of the important things for the development of tourism is facilitation. It is not uncommon for tourists to visit a place because they are attracted by the facilities that can be obtained, as well as no fewer tourists cancel a visit to a place because they feel they have no facilities;

- Accessibility to and from tourist destinations. A country as a tourist destination that expects more tourists to come, stay longer, and spend more money to buy anything at the tourism site must be able to provide convenience for tourists candidate. What is meant by accessibility is none other than all the facilities provided not only to prospective tourists who want to visit but also convenience when they travel in the tourist destination.

Dimyanti (2002) states that facilities are physical services which support non-physical services. Various facilities are:

- Physical Facilities. Is in the form of bedrooms, seating, tables, places to eat, karaoke places, places of worship, sports/body care and toilets;

- non-physical facilities are in the form of: clean air, music and others.

According to Spillane (1994), facilities are facilities and infrastructure that support the operation of tourism objects to accommodate all tourist needs, not directly encourage growth but develop at the same time or after attractions develop.Based on Spillane's theory in Mukhlas (2008), facilities can be grouped into 3 (three) parts, namely:

- The main facility is the one that is needed or felt very necessary as long as visitors are in a tourist attraction;

- Supporting facilities, facilities which in proportion are complementary to the main facilities so that tourists will feel more comfortable at home;

- Supporting facilities are actually the main complement so that whatever the tourists need while visiting tourist attractions are fulfilled.

Sellers can understand consumers well through the experience of selling products directly to them.But along with the fast growing of a company and the widespread market, marketing decision makers lose contact with consumers. Therefore, to be able to understand their behavior, consumer research is needed.For that matter, consumers must make a decision.Decisions that have been chosen by a consumer will be continued with action. The effort to learn it must be related to the social status of the consumer, method, time, place and reason for the purchase.

Consumer behavior will determine the decision-making process in their purchase, the process is a problem-adjustment approach consisting of five stages carried out by consumers, i.e. problem recognition, information seeking, alternative assessment, decision making, and post-purchase behavior (Kotler, 2004).

The purchase decision is the attitude of a person to buy or use a product in the form of goods or services that are believed to be satisfying and willingness to bear the risks that may arise.Purchasing decisions taken by buyers are actually a collection of organized decisions.(Adirama2012).

Based on Basu Swastha and T Hani Handoko (2012), purchasing decisions are an approach to solve problems in human activities to buy goods or services in fulfilling their wants and needs which consist of the introduction of needs and desires, information seeking, evaluation of alternative purchases, decisions purchase, and behavior after purchase.

Sangkaeng, Mananeke, and Oroh (2015) carried out a research about the effect of Image, Promotion and Service Quality on Tourist Satisfaction at Attractions in Bunaken Marine Park, North Sulawesi.The result of the simultaneous test shows that Tourism Promotion and Tourism Site Services Quality simultaneously have a positive influence on Tourist Satisfaction, and Tourism Promotion partially has a significant influence on Tourist 
Satisfaction, Tourism Site Services Quality partially has an influence on Tourist Satisfaction and Tourism Image partially has no significant influence on Tourist satisfaction.

Facilities are means and infrastructure that support the operation of tourism objects to accommodate all tourist needs. At a price level that is almost the same, the more complete the facilities provided by the company, the more satisfied the customer will be and she/he will continue to choose the location of the tour as a priority choice based on the perception she/he has on the available facilities.

How important tourist facilities are to increase the number of tourist visits makes many researchers conduct a study on the influence of facilities on consumer purchases.A study conducted by Lempoy, Mandey, and Loindong (2015) entitleThe Inluence of Price, Location, and Facilities on the Decision of Visiting Toar Lumimuut Tourism Park. The results of the research show that both simultaneously and partially Price, Location, and Facilities have a significant influence on the decision to use the services of Toar Lumimuut Tourism Park.

Rosita et al. (2016) carried out a study to look at the effect of tourist facilities and service quality on visitor satisfaction in the wildlife park. The results of their research show that tourist facilities and service quality influence visitor satisfaction. The higher the facilities provided, the higher the satisfaction that consumers feel.

Other research related to tourism facilities was carried out by Sulistiyana et al (2015).They examined the influence of tourist facilities and prices on customer satisfaction.The results of their simultaneous research show that facilities and prices affect consumer satisfaction.But overall, the influence of facilities and prices on customer satisfaction is only explained by 53 percent.

From the objectives and research problems, prepositions can be formed, namely:

Promotion Factor. Promotion refers to various activities carried out by the company to communicate the goodness of its products and persuade customers and target consumers to buy the product.Therefore, it can be concluded that the basis of promotional activities is corporate communication with consumers to encourage the creation of sales.Today's promotional activities are increasingly important and needed.This happens because of the long distance between producers and consumers, the number of potential customers getting higher, and the existence of intermediaries. Through this intermediary, the company no longer communicates with consumers.

Promotion is an important tool in global marketing where it must be designed to foster good deeds and provide accurate and timely information, especially in crisis situations. Poorly designed promotions can lead to unwanted publicity and loss of customers. Promotion consists of all activities that try to stimulate the action of buying a product which is fast or in a short time, Keegan (2007).Swastha and Handoko (2008) propose that promotion is a shortterm incentive to encourage the purchase or sale of a product or service.Tjiptono (2008), defines that promotion is a form of marketing communication. What is meant by marketing communication is marketing activities that seek to disseminate information, influence and remind the target market of the company and its products to be willing to accept, buy, and be loyal to the products or services offered by the company.

From the description above, it can be drawn a proposition that the promotion of tourism in Manado city plays an important role to attract tourists to come.

Facility Factor. Facilities are appearance, capability of infrastructure, and the condition of the surrounding environment in showing their existence to the external side including physical facilities (buildings), equipment and equipment (Lupioadi, 2008).

Tourist facilities, according to Mill (2000: 30), are supportting services that are always ready to be used by tourists and the service offers quality and prices which suit the needs of tourists.

Spillane (1994) said that facilities are means and infrastructure that support the tourism objects operational to accommodate all tourist needs, not directly encourage growth but develop at the same time or after attractions develop.

From the description above, it can be drawn a proposition that the facility is physical equipment provided by a tourist attraction manager to support and facilitate tourist activities in Manado city while at a tourist attraction so that visitor's needs are met. 


\section{METHODS OF RESEARCH}

These research results are expected to be a valuable input for the government in terms of policy determination, for investors in making investment decisions appropriately, moreover, the results of this study can be an important reference for the similar research for applied interests and the interests of science development.

According to Sugiyono (2013), a research method is a scientific way to obtain data with specific purposes and uses. Moleong (2005: 4) says a qualitative descriptive approach is a research approach in which the data collected is in the form of words, images and not numbers. Those data can be obtained from interviews, field notes, photos, videotapes, personal documentation, notes, or memos and other documentation. This was a qualitative descriptive research.

The population of this research was tourists who made a journey to Manado city. The sample needed by researchers were as many as 10 tourists who visited Manado city. Those 10 tourists would be interviewed then.

This research was conducted in Manado The object of this research is tourists visiting Manado city.

The data analysis technique used is an interpretive analysis technique by looking at how to understand deep data (Poerwandari, 2007).The researcher interpreted the concept of social capital obtained from observations and interviews. follows:

Based on the hypothesis stated above, the variables to be analyzed can be defined as

Promotion is a form of marketing communication.Marketing communication is an activity that tries to disseminate information, influence and remind the target market of the company and its products to be willing to accept, buy, and be loyal to the products or services offered by the company.From the description above, questions can arise; they are:

- What kind of promotion which can reach all tourists?

- How many tourism promotions in Manado do tourists see?

- How does the quality of tourism promotions affect tourists?

Tourism facilities are all facilities whose functions fulfill the needs of tourists who stay for a while in the tourist destination they visit, where they can relax and participate in activities available in the tourist destination.From the description above, questions can arise; they are:

- Have accommodation in Manado city (hotels, motels, apartments, etc.) met the needs of tourists?

- Do restaurants, bars and cafés in Manado meet the needs of tourists?

- Has tourism transportation in Manado city been able to meet the needs of tourists?

- Have retail outlets (shops, travel agents, souvenir shops) met the needs of tourists?

\section{RESULT OF STUDY}

Interview result with informant:

Mr. Hasan from Oman. Questions about promotion can reach all tourists, Mr. Hasan said that the promotion carried out had not reached all tourists.According to them, there are many friends and relatives who have not received yet information about tourism in Manado.For many tourism promotions that can be seen by Mr.Hasan, he said that he hadn't seen so much as promoting tourism in the Lombok region.While the quality of tourism promotion, according to him, is quite good.Questions about facilities, according to Mr. Hasan, the hotel accommodation where he stayed in Manado was good enough.As for the restaurant, bar, and fund facilities, the café is good even with local decorations and music.For other supporting facilities such as souvenir shops, is still lacking, but for ticket sales, travel is good.

Mrs. David and Mrs. Keith from England. According to both of them, there is no promotional information about Manado in the UK. They only Manado city when they were in 
Bali.Tourism promotion of Manado city they saw quite a lot in Bali.By looking at the promotion, they come to Manado.A matter of facility, according to them, it seems Manado to be fixing tourist facilities. The hotel where they stayed was quite adequate.As for transportation, Mr. David and Mrs. Keith said it was still lacking.They say this statement because they compare it to facilities in Bali.They said that a matter of retail outlets is still lacking.

Mrs. Iriana from palembang. A matter of promotion, according to Mrs. Iriana, promotions carried out by Manado city government and the private sector involved have been able to reach almost all tourists. According to him, she saw a lot of promotions about the city of Manado.He saw through a newspaper, online media, and also social media like Facebook.According to him, the quality of Manado city promotion is good.She saw visually through a video that shows the development of the Manado city in general, moreover tourist destinations in Manado and its surroundings are good so she is interested and comes to visit Manado.If Manado was only famous for Bunaken, it turned out that many tourist destinations had just been opened. According to Mrs. Iriani, a matter of tourism supporting facilities, such as hotels and other homestay is good enough.To find halal places to eat can also be easily obtained.According to him, restaurants that specialize in selling grilled fish are good, because Manado is on the coastline. But she suggested keeping clean so visitors can be more comfortable.But she suggested keeping clean so visitors can be more comfortable. There is public transportation and land or sea rent transportation that supports the tourism sector in Manado.There are quite a lot of retail outlets and good support and help for tourists who come to Manado city.

Mr. Gerald and Mrs. Jane from Germany. A matter of Promotion, according to Mr. Gerard and Mrs. Jane, they can access information about the promotion of tourism in Manado city. According to them, promotion about the city of Manado could also be received by friends in Germany.As for the number of promotions about Manado city they see, that the quantity to see promotions is quite a lot.Some media, according to them, show quite a lot the promotion of Manado city. They said that the quality of Manado city's tourism promotion is quite good.It shows tourism destinations and culture, as well as activities that support tourism development very well to sell. A matter of facilities, according to them, lodging or hotels in Manado city are quite good and many.It would be better if lodging or hotel facilities in Manado add transportation facilities. Restaurants or food stall in Manado are partially good but some still need touch to add facilities. Cafes located in hotels and malls are good enough too.But for traditional eating places, such as grilled fish stall, will be more interesting if added or displayed regional cultural. While transportation has been good because they find it easy to get transportation.Other supporting facilities, retail outlets are good and can help them when they need tourism equipment, also for their friends and relatives.

Mr. Martin, David, and Mrs. Sue from Australia. A matter of promotion, according to them, the government's promotional activities to introduce Manado City could reach many tourists.Bunaken Marine Park is the first tourist spot they know.And now there are many new tourist attractions in Manado city and its surroundings. They see that the quantity of tourism promotions seen by tourists is not too much.Tourism promotions will be usually widely circulated on social media later if there are tourism activities or festivals. In their opinion, the quality of tourism promotion in Manado City is good.While the accommodation in Manado city, according to them, has increased a lot.According to them, Manado had fulfilled the needs of tourists. They said that the restaurants, bars, and cafes in Manado City have been able to meet their needs.A matter of transportation.According to them, transportation in Manado City can fulfill them. Retail outlets in Manado city have been able to meet their needs, although it is still somewhat lacking.

You Mei Ling and Tjia Bun Hoa from Tiongkok. They opine that Manado city tourism promotion is good and can reach many tourists.Meanwhile, a matter of how much tourism promotion is seen by tourists, they said that they can see tourism promotion in Manado City. The quality of tourism promotion in Manado city was influential so they decided to visit Manado.A matter of tourist facilities, firstly related to accommodation, has been good.Whereas restaurants, bars, and cafes can meet their needs.A matter of transportation, 
whether it is able to meet the needs of tourists, they answer that transportation in Manado city has fulfilled the needs of tourists.

The results of this study show that not all tourists visiting Manado received information on tourism promotion in Manado city. The results of this study support the study conducted by Mingkid (2015) that the use of communication media in tourism promotion activities has not made the promotion of tourism run well.

The result of this study, which is about tourism facilities in Manado city having an influence on tourists' decision to come to Mando supports the previous study carried out by Lempoy et.al (2015) where one of the variables observed is facility affected the decision to use the service of Sonder Toar Lumimuut Tourism Park.

Activities that promote tourism in Manado city should be carried out continuously by gradually continuing to change the themes of activities. The Manado Fiesta event, for example, is one of the very good activities for the tourism sector in Manado. Tourist facilities that have long existed, then added, even renovated will make tourists feel at home. Multiplayer effects will be felt by the government, the private sector, and the community.Tourists who come will spend money on lodging, sightseeing, eating, and buying souvenirs.

\section{CONCLUSION}

Based on the results of the analysis, the research conclusions can be stated as follows:

- The tourism promotion in Manado City can reach most tourists;

- Manado City tourism promotion can be seen by many tourists;

- The quality of tourism promotion in Manado City has an effect on tourists who come to Manado;

- Accommodation in Manado City can meet the needs of tourists;

- Restaurants, bars, and cafes in Manado City can meet the needs of tourists;

- Transportation in Manado city can meet the needs of tourists;

- Retail outlets in Manado city have been able to meet the needs of tourists.

\section{SUGGESTIONS}

These research results are still limited and require improvement in the next study.Based on the results of analysis and conclusions, suggestions can be given as follows:

- It needs improvement in tourism promotion in Manado city so that it is more able to reach many tourists;

- It needs improvement in the quality of tourism promotion in Manado city to attract more tourists to come to Manado;

- It better improves the accommodation function so that tourists are more satisfied with the services provided;

- Traffic jam problem in Manado city needs to manage well for tourists' convenience.

\section{REFERENCES}

1. Afifudin. (2016). Pengaruh Lokasi, Promosi Dan Harga Terhadap Kepuasan Konsumen Di Wisata Bahari Lamongan.Jurnal IImu dan Riset Manajemen, 5(12), 25-33.

2. Assauri, S. (2011). Manajemen Pemasaran Dasar, Konsep, dan StrategiPT.Jakarta:Grafindo Persada.

3. Babin, Z. (2011). Menjelajahi Riset Pemasaran.Jakarta:Salemba Empat.

4. Basu, S .(2009).Manajemen Penjualan. Yogyakarta: BPFE.

5. Basu, S., and Hani, H. (2008). Manajemen Pemasaran:Analisa Perilaku Konsumen. Yogyakarta:Penerbit BPFE

6. Elfie, M. (2015).Penggunaan Media Komunikasi Promosi Pariwisata Oleh Pemerintah Kota Manado.Sosiohumaniora, 18(3), 33-39. 
7. Keegan, W. J. (2007).Manajemen Pemasaran Global.Jakarta: PT Indeks Kelompok Gramedia.

8. Kotler, P. (2001).Manajemen Pemasaran:Analisis, Perencanaan, Implementasi, danKontrol. Jakarta: PT.Prehallindo.

9. Kotler, P., and Gary, A. (2004). Dasar-Dasar Pemasaran. Translated by Alexander, S. Jakarta:Indeks.

10. Lempoy, N. C., et al. (2015). Pengaruh Harga, Lokasi, Dan Fasilitas Terhadap Keputusan Menggunakan Jasa Taman Wisata ToarLumimuut (Taman Eman) Sonder. Jurnal EMBA, 3(1), 1072-1083.

11. Lexy, J. M. (2005). Metodologi Penelitian Kualitatif. Bandung:Remaja Rosdakarya.

12. Lupiyoadi, R.(2013). Manajemen Pemasaran Jasa. Jakarta:Salemba Empat.

13. Mill, R. C. (2000).Tourist The International Business.Jakarta:PT Raja Grafindo Persada.

14. Shimp, T. A. (2003).Periklanan Promosi Aspek Tambahan Komunikasi Pemasaran Terpadu.Jakarta:Erlangga.

15. Spillane, J. (1994).Pariwisata Indonesia: Siasat Ekonomi dan Rekayasa Kebuadayaan. Yogyakarta: Kanisius.

16. Sulistiyana., et al. (2015).Pengaruh Fasilitas Wisata Dan Harga Terhadap Kepuasan Konsumen (Studi Pada Museum Satwa).Jurnal Administrasi Bisnis (JAB), 25(1), 120 126.

17. Tjiptono, F. (2008). Pemasaran Jasa.Malang:Bayu Media.

18. Tjiptono, F. (2001).Strategi Pemasaran. Yogyakarta:Penerbit Andi. 